De Ondernemerstaad voor Suriname zond ons het verslag, door dr. Fernandes openbaar gemaakt over de proeven, die hij gedurende een tweetal jaren in Suriname deed ter verbetering van geur en smaak ens. van de Suriname Liberia koffie.

Op verzoek der redactie was Dr. C. J.J. van Hall bereid, dit verslag in ons tijdschrift te bespreken.

\title{
DE PROEVEN VAN DR. FERNANDES IN DE KOFFIE-PROEFFABRIEK IN SURINAME
}

DOOR

DR. C. J. J. VAN HALL

De Surinaamsche Liberiakoffie staat, in het algemeen gesproken, in een minder goede reuk. Het product van de eene plantage staat echter beter aangeschreven dan dat van de andere.

Een onderzoek, door Dr. D. S. Fernandes eenige jaren geleden ingesteld, bracht aan het licht, dat de bereidingswijze te wenschen overliet en dat door een snellere droging bij een hoogere temperatuur een verbetering in de qualiteit te bereiken was. De vraag werd toen onder de oogen gezien, op welke wijze het door Dr. Fernandes gevonden principe in het groot zou zijn toe te passen.

Door bemiddeling van den Ondernemersraad voor Suriname zijn toen gelden bijeengebracht, die het mogelijk hebben gemaakt, dat door de Firma Gebr. Stork \& Co. onder leiding van Dr. Fernandes nabij Paramaribo een kleine proeffabriek werd gebouwd, waar de methode in toepassing zou worden gebracht.

Het eerste verslag van de werkzaamheden ligt thans voor ons. Dr. Fernandes geeft hierin een uitvoerig overzicht van den gang der bereidingsproeven, hij beschrijft de onderdeelen van de fabriek en de ervaringen, die ermee werden opgedaan, hij geeft verder een uitvoerig verslag van de drogingsproeven, en tenslotte worden de financieele uitkomsten vermeld.

$\mathrm{Bij}$ het ontwerpen van de fabriek gingen Dr. Fernandes en de firma Stork uit van den Guardiola-droger, die veel in Suri- 
name gebruikt wordt als cacao- en koffiedroger, doch met het oog op de noodzakelijkheid snel te drogen en de fabriek een grootere capaciteit te geven dan de Guardiola-droger heeft, moest een installatie worden samengesteld, die in veel opzichten van de bestaande afweek, al werd het principe behouden van de draaiende geperforeerde trommel, waarin heete lucht wordt gebracht.

Niet alleen het vraagstuk der verbeterde droging werd onder de oogen gezien, ook werd in de nieuwe fabriek getracht verbetering te brengen in het pulpen en het wasschen.

Het pulpen geeft bij de Liberia-koffie door het harde vruchtvleesch meer moeilijkheden dan bij andere koffiesoorten en het is bezwaarlijk te pulpen zonder een eenigszins belangrijk verlies aan boon. De gewichtsverhouding van droge boon tot bes is bij

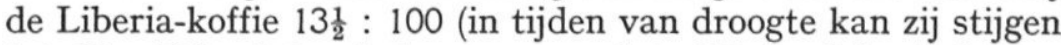
tot $20: 100$ ), dat wil dus zeggen, dat $100 \mathrm{~kg}$ Liberia-bessen bij ideale bereiding $13 \frac{1}{2} \mathrm{~kg}$ droge marktkoffie leveren. Bij de bereiding op de plantages komt men echter, naar Dr. Fernandes vernam, nooit boven een ,,uitlevering" van $10 \frac{1}{2}$. Het schijnt wel wenschelijk, dat door den onderzoeker zelf nog eens wordt nagegaan of dit inderdaad zoo is. Maar hoe dit ook zij, wij mogen wel met Dr. Fernandes aannemen, dat in Suriname bij het pulpen met den gewonen Schaapspulper een niet onbelangrijk deel verloren gaat. Bij de proefnemingen in de proeffabriek werd uit een partij bessen een uitlevering van $11-12 \%$ verkregen, terwijl de Schaapspulper bij een ander deel van dezelfde partij slechts een uitlevering van $10 \%$ gaf. De winst had dus niet minder dan $10-20 \%$ bedragen (10 à 20 balen op iedere 100 balen). Dr. Fernandes verwacht nu, dat met de nieuwe door hem gevonden pulpmethode zeer waarschijnlijk een gemiddelde uitlevering van $11 \frac{1}{2}$ verkregen zal worden. Maar dit zal toch nog eerst in het groot nagegaan moeten worden. Het volgende rapport zal ons hierover zeker meer positiefs zeggen. Komt de verwachting uit, dan is een mooi resultaat verkregen.

Bij de proeven betreffende het wasschen werd gevonden, dat ook bij de Liberia-koffie, evenals bij de Robusta op Java, de fermentatie zonder eenig bezwaar kan worden uitgeschakeld. De op Java gevolgde methode - waarbij de bekende „Rapido” of een soortgelijke waschmachine wordt gebruikt - werd ook hier met succes toegepast: de gepulpte koffie wordt dadelijk in den wasscher gebracht en zonder bijvoeging van water worden de 
boonen eerst eenigen tijd door ronddraaiende schoepen tegen elkaar en tegen de schoepen en den wand gewreven, vervolgens wordt water toegevoegd en wordt het vruchtslijm weggespoeld. Deze twee bewerkingen worden herhaald, totdat het water geheel helder afvloeit. Deze manier van wasschen, waarbij dus het omslachtige fermentatieproces is uitgeschakeld, heeft het voordeel van snelheid, en, zooals Dr. Fernandes vond, nog een ander, voor Suriname groot voordeel, nl. dat er geen zoet water voor noodig is en het brakke rivierwater gebruikt kan worden.

Een groot deel van het rapport is gewijd aan de drogingsproeven. Het doel was een product te verkrijgen, goed van geur en smaak en van de gewenschte blauwe kleur. Bij deze proeven, waarbij verschillende verwarmings-methoden werden beproefd, gelukte het eerst na vele proefnemingen een systeem te vinden, waarvan de resultaten bevredigend werden geacht. Bij dit systeem wordt de koffie tijdens de vulling van den trommel luchtdroog geblazen met lucht van $100^{\circ} \mathrm{C}$, zoodat bij het begin van de droging de temperatuur van de boonen de $40^{\circ} \mathrm{C}$ niet overschrijdt; de droging geschiedt dan verder onder toevoer van heete lucht van ongeveer $350^{\circ} \mathrm{C}$.

Bij het pellen deed zich aanvankelijk het bezwaar voor, dat de blauwe kleur steeds veranderde in een grijze. Bij een van de proeven werd de koffie, bij gebrek aan een droogvloer, op het gele zand van het fabrieksterrein in de zon uitgespreid tengevolge waarvan de hoornschil-koffie met een uiterst dun laagje zand bedekt werd. Na de pelling viel het dadelijk op, dat de boon egaal blauw was gebleven. Hetzelfde resultaat werd ook verkregen door zand aan de natte gewasschen hoornschil-koffie toe te voegen. Zoo werd door een gelukkig toeval een pelmethode gevonden, die de blauwe kleur intact laat. Het gelukte Dr. Fernandes nog niet een verklaring te vinden voor de gunstige werking van het zand.

De kosten van bereiding in de proeffabriek lieten zich becijferen op gemiddeld 6,3 ct per $\mathrm{kg}$. Wanneer echter met de verbeterde pulpmethode een hooger uitleveringscijfer bereikt wordt, hoopt Dr. Fernandes de prijs tot 5 ct te doen dalen en hij verwacht een verdere reductie met $1 \mathrm{ct}$, wanneer de beschikking wordt verkregen over een zuiggasmotor, waarbij in plaats van andere brandstof de hoornschil vergast wordt. Verdere proeven zullen moeten leeren, in hoever deze verwachtingen vervuld kunnen worden.

In èèn opzicht stelt het rapport eenigszins teleur. De groote 
vraag is immers, welke qualiteits-verbetering en welke prijsverhooging door de nieuwe bereidingsmethode verkregen wordt. Op deze vraag krijgen wij echter nog geen volkomen bevredigend antwoord. Wel vinden wij de prijzen vermeld, die voor een aantal partijen (in het geheel 560 balen )te Paramaribo door eenige handelshuizen - in de meeste gevallen was de firma C. Kersten \& Co kooper - betaald werden, en daarnaast de prijzen op de betreffende data voor ,„prima Liberia” van de plantages betaald, en wij zien dan, dat de eerstgenoemde prijzen één of een paar centen hooger zijn dan de laatstgenoemde, maar, al is dit zeker aanmoedigend, wij krijgen hiermee toch geen goeden indruk van de qualiteitsverbetering, die met de nieuwe bereidingsmethode verkregen is. Wij zouden het op prijs stellen in een volgend rapport uitvoerig te worden ingelicht over de prijzen, die gemaakt zijn voor niet te kleine partijen koffie van verschillende plantages, van welke partijen een deel bereid was op de plantage zelf en een deel bereid in de Proeffabriek, en daarbij tevens de uitkomsten te vernemen van de sortatie vóór den verkoop - een strengere sortatie kan alleen reeds een prijsverhooging geven van enkele centen -, terwijl de verkoop dan zou moeten plaats hebben door bemiddeling van koffie-makelaars te Amsterdam. Zoodoende zouden wij dan tevens ingelicht worden over de belangrijke vraag, of het verschil in kwaliteit, dat de koffies der verschillende Surinaamsche plantages aanwijzen, het gevolg is van verschil in bereiding dan wel veroorzaakt wordt door andere omstandigheden.

Met belangstelling zullen wij het verdere verloop van de proeven van Dr. Fernandes volgen. 